\title{
PERUBAHAN SISTEM PELAYANAN MAKANAN PADA USAHA KULINER SELAMA MASA PANDEMI COVID-19 DAN ERA KEBIASAAN BARU DI KOTA MAKASSAR
}

\section{Article history \\ Keywords: \\ Covid-19 \\ Pandemic \\ Food safety \\ Food service \\ Qualitative}

ARTICLE INFO

Submitted : 2020-10-15

Revised : 2020-10-29

Accepted : 2020-10-31

\section{Kata Kunci:}

Covid-19

Pandemi

Keamanan pangan

Pelayanan makanan

Kualitatif

\author{
Nurbaya $^{1}$, Wahyu Chandra ${ }^{2 \bowtie}$ Ansar $^{3}$ \\ ${ }^{1}$ Jurusan Gizi Poltekkes Kemenkes Mamuju \\ ${ }^{2}$ Jalin Institute Makassar \\ ${ }^{3}$ Jurusan Gizi Poltekkes Kemenkes Palu
}

\begin{abstract}
Food safety is one of the people's concerns in buying and consuming food during the Covid-19 pandemic. This requires culinary entrepreneurs to meet food safety standards in the food processing system. This study aims to determine the food service system carried out by culinary entrepreneurs during the Covid- 19 pandemic and in the era of new normal in Makassar City. With a qualitative approach, 33 informants were selected purposively to be involved in this study which was distributed into 17 in-depth interviews and 3 FGDs. Data analysis was carried out in three stages, namely data reduction, data presentation, and conclusion or verification. This research found that culinary entrepreneurs applied health standards in their restaurants by providing handwashing facilities, barrier plastic, keeping tables/chairs apart, and requiring consumers to wear masks. Food processing requires food processors to use disposable plastic gloves and masks as well as tighter food packaging. It is concluded that culinary entrepreneurs have implemented safety and health standards in the food service system both in food processing and food packaging. It is highly recommended that culinary entrepreneurs perform routine cleaning and disinfecting at their restaurants so that efforts to prevent Covid-19 can be maximized, especially in the culinary business sector.
\end{abstract}

Keamanan pangan menjadi salah satu perhatian masyarakat dalam membeli dan mengonsumsi makanan selama pandemi Covid-19. Hal ini menuntut pengusaha kuliner agar memenuhi standar keamanan pangan pada sistem pengolahan makanan. Penelitian ini bertujuan untuk mengetahui sistem pelayanan makanan yang dilakukan oleh pengusaha kuliner selama masa pandemi Covid-19 dan pada era kebiasaan baru di Kota Makassar. Dengan pendekatan kualitatif, sebanyak 33 informan dipilih secara purposive terlibat dalam penelitian ini yang terbagi ke dalam 17 wawancara mendalam dan 3 FGD. Analisis data dilakukan melalui tiga tahap yaitu tahap reduksi data, penyajian data, dan kesimpulan atau verifikasi. Penelitian ini menemukan bahwa pengusaha kuliner menerapkan standar kesehatan di rumah makan/restoran mereka dengan menyediakan fasilitas cuci tangan, pembatas plastik, menjaga jarak meja/kursi dan mewajibkan konsumen menggunakan masker. Proses pengolahan makanan dengan mewajibkan pengolah makanan menggunakan masker dan sarung tangan plastik sekali pakai serta pengemasan makanan yang lebih ketat. Berdasarkan hal tersebut disimpulkan bahwa pengusaha kuliner telah menerapkan standar keamanan dan kesehatan pada sistem pelayanan makanan baik pada proses pengolahan dan pengemasan makanan. Sangat direkomendasikan agar pengusaha kuliner melakukan pembersihan dan disinfektan secara rutin pada rumah makan/restoran mereka, agar upaya pencegahan Covid-19 lebih maksimal khususnya di sektor usaha kuliner.

\section{Corresponding Author:}

Wahyu Chandra

Jalin Institute Makassar

Telp. 081355223311

Email: jalininstitute@gmail.com

\section{PENDAHULUAN}

Virus dapat mengontaminasi berbagai jenis produk makanan dan bahkan dapat infektif dalam makanan hingga 4 minggu. Makanan berperan penting dalam penularan virus seperti Norovirus (NoV) dan virus hepatitis A (HAV). Kedua virus ini sangat mudah ditularkan ke 
manusia melalui makanan atau air yang terinfeksi. (Ceylan, Meral, \& Cetinkaya, 2020)

Meski WHO menyatakan bahwa Coronavirus disease 2019 (Covid-19), penyakit yang disebabkan oleh novel coronavirus SARSCoV-2, sebagai pandemi. (WHO, 2020c) Namun berdasarkan penelitian pada wabah virus korona terutama MERS-CoV dan SARSCoV menunjukkan bahwa makanan bukanlah jalur penularan virus. (Han, Zhang, He, \& Jia, 2020), (Centers for Disease Control and Prevention, 2020a) Karena virus tersebut membutuhkan hewan atau manusia sebagai host untuk bertumbuh. (Olaimat, Shahbaz, Fatima, Munir, \& Holley, 2020)

Cara penularan COVID-19 adalah melalui manusia ke manusia, terutama melalui droplet orang yang terinfeksi saat bersin, batuk, atau saat bernapas. (European Commission.
Directorate-General for Health and Food Safety., 2020) Penularan dapat terjadi melalui individu yang terinfeksi virus yang menyentuh makanannya lalu orang lain yang sehat membersihkan sisa makanan atau tempat makannya lalu menyentuh daerah wajar seperti mata dan mulut. (Naja \& Hamadeh, 2020) Hal inilah menjadi kekhawatiran konsumen dalam mengonsumsi makanan yang disajikan oleh pengusaha kuliner.

Selain itu, adanya pembatasan terhadap aktivitas masyarakat termasuk berkumpul di tempat umum seperti pasar, pusat perbelanjaan, perkantoran, termasuk rumah makan berdampak pada pengusaha kuliner yang ada di Makassar sebagai salah satu kota yang menerapkan Pembatasan Sosial Berskala Besar (PSBB). (Kemenkes RI, 2020)

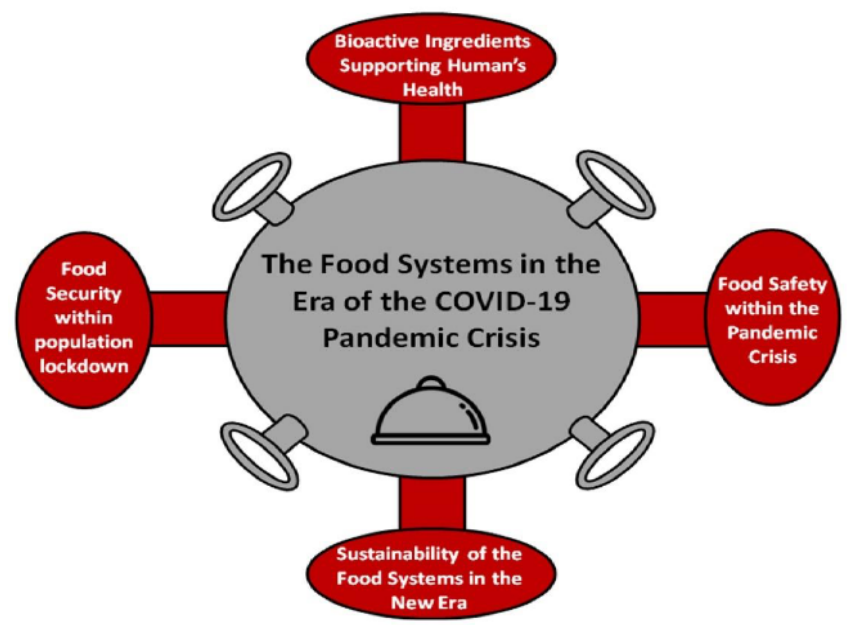

Gambar 1. Sistem pangan pada masa pandemic Covid-19 (Galanakis, 2020)

Menurut Galanakis (2020), seperti pada gambar 1 bahwa sistem pangan telah berubah selama masa pandemi ini. Setidaknya komponen keamanan pangan dan kandungan bioaktif dalam pangan menjadi pertimbangan masyarakat dalam upaya pemenuhan pangan rumah tangga. (Galanakis, 2020) Termasuk perhatian masyarakat terhadap makanan yang dibeli dari luar rumah seperti dari rumah makan/restoran. Sehingga upaya pencegahan pada proses penyediaan makanan menjadi sangat penting dalam mengurangi risiko penularan virus.

Hal inilah yang menjadi latar belakang penelitian ini dilakukan yaitu untuk mengetahui perubahan sistem pelayanan makanan oleh pengusaha kuliner selama masa pandemi
Covid-19 dan pada era kebiasaan baru di Kota Makassar.

\section{METODE PENELITIAN Jenis Penelitian}

Penelitian ini menggunakan metode kualitatif dengan pendekatan deskriptif yang bertujuan untuk mengetahui gambaran perubahan standar pelayanan makanan yang diterapkan oleh pengusaha kuliner selama pandemi Covid-19 dan era kebiasaan baru di Kota Makassar. Proses pengumpulan data dilakukan di Kota Makassar setelah diberlakukannya aturan era kebiasaan baru yaitu pada bulan September - Oktober 2020.

Pengumpulan data dilakukan dengan cara wawancara mendalam (in-depth interview) 
dan grup diskusi terarah (focus group discussion). Wawancara menggunakan pedoman wawancara semi-terstruktur yang dilakukan selama 40-60 menit dalam bahasa Indonesia. Sedangkan untuk FGD dilakukan selama 100 - 120 menit.

Wawancara mendalam dilakukan dengan tatap muka secara langsung di rumah atau rumah makan/restoran informan. Jumlah peserta FGD dibatasi maksimal hanya enam orang dan dilakukan di ruang pertemuan yang luas dengan tetap memperhatikan protokol kesehatan seperti mencuci tangan dengan sabun dan air mengalir, menggunakan hand sanitizer, jaga jarak dan menggunakan masker.

\section{Informan}

Informan dalam penelitian ini adalah pengusaha kuliner yang menjual makanan dan minuman baik secara langsung (offline) maupun penjualan online di Kota Makassar. Pemilihan informan dilakukan secara purposive berdasarkan kriteria informan yang telah ditentukan. Adapun kriteria yang telah ditentukan yaitu jenis kelamin, kelompok usia, penghasilan per-hari, lama usaha dan jumlah karyawan. Proses wawancara dilakukan setelah mendapat persetujuan dari informan.

Semua wawancara direkam menggunakan alat perekam suara lalu ditranskripsi dalam bentuk teks. Hasil transkrip dibaca ulang dan dicocokkan dengan rekaman untuk memastikan bahwa hasil transkrip sudah sesuai.

\section{Analisis Data}

Analisis data dilakukan melalui tiga tahap yaitu tahap reduksi data, penyajian data, dan kesimpulan atau verifikasi. Pada proses reduksi data, peneliti mengelompokkan data dan membuang yang tidak relevan serta mengorganisasi data sedemikian rupa sehingga kesimpulan akhir dapat diambil.

Selanjutnya adalah tahap penyajian data. Pada tahap ini peneliti melakukan klasifikasi data untuk mempermudah dalam penarikan kesimpulan. Hasil penelitian kemudian disajikan dalam bentuk narasi.

\section{HASIL PENELITIAN}

Sebanyak 33 informan yang terlibat dalam penelitian ini yang terdiri atas 17 informan terlibat dalam wawancara mendalam. Dan sebanyak 16 informan terlibat di dalam tiga FGD. Sebagian besar informan berusia antara 31-40 tahun (54,5\%), memiliki pendidikan S-1 $(78,8 \%)$ dan telah memulai usahanya antara satu sampai dua tahun $(45,5 \%)$.

Tabel 1. Karakteristik Informan $(n=33)$

\begin{tabular}{lcc}
\hline \multicolumn{1}{c}{ Karakteristik } & n & Persentase (\%) \\
\hline Jenis kelamin & & \\
Laki-laki & 20 & 60,6 \\
Perempuan & 13 & 39,4 \\
\hline Usia (tahun) & & \\
$21-30$ & 5 & 15,2 \\
$31-40$ & 18 & 54,5 \\
$>40$ & 10 & 30,3 \\
\hline Pendidikan terakhir & & \\
SMA & 2 & 6,1 \\
D-III & 1 & 3,0 \\
S-1 & 26 & 78,8 \\
S-2 & 4 & 12,1 \\
\hline Penghasilan per hari & & \\
>500 ribu & 12 & 36,4 \\
500 ribu - 1 juta & 9 & 27,2 \\
$>1$ juta & 12 & 36,4 \\
\hline Jumlah karyawan & & \\
Tidak ada & 10 & 30,3 \\
1 orang & 12 & 36,4 \\
$>1$ orang & 11 & 33,3 \\
\hline Lama usaha & & \\
$<1$ tahun & 8 & 24,2 \\
1 - 2 tahun & 15 & 45,5 \\
>2 tahun & 10 & 30,3 \\
\hline
\end{tabular}

Penelitian ini menemukan tiga tema utama yang menjadi perubahan dalam sistem pelayanan makanan yang dilakukan oleh pengusaha kuliner dalam menjalankan usaha mereka selama masa pandemi Covid-19 dan era kebiasaan baru, sebagaimana yang ditunjukkan pada tabel 2 berikut.

\section{Peningkatan Penjualan Makanan/Minuman yang Dilakukan Online Selama Masa PSBB}

Selama masa PSBB, sebagian besar pengusaha kuliner masih tetap melakukan penjualan secara online. Baik yang dilakukan di aplikasi penyedia jasa pesan makanan online ataupun melalui sosial media seperti Instagram, Facebook, dan pemesanan melalui aplikasi WhatsApp.

Berdasarkan hasil wawancara, diperoleh gambaran bahwa meski mereka tidak membuka rumah makan/restoran, mereka tetap 
melakukan penjualan secara online. Beberapa informan mengatakan bahwa mereka mengalami peningkatan penjualan makanan dan minuman selama masa PSBB. Seperti informasi yang disampaikan oleh informan sebagai berikut:

"Kami tetap jualan makanan lewat online, alhamdulillah lumayan yang pesan. Tapi kami tetap berharap tidak ada PSBB lagi dan corona segera hilang” (Informan I, IDI).
"Selama masa PSBB kemarin rumah makan kami tutup tapi alhamdulillah pemesanan makanan secara online justru banyak" (Informan AB, IDI).

"Kami tetap melakukan penjualan online melalui group WhatsApp dagang yang ada di kompleks kami. Alhamdulillah banyak yang pesan. Mungkin karena mereka takut keluar belanja makanan." (Informan D, IDI).

\section{Tabel 2. Perubahan dalam Sistem Pelayanan Makanan Pengusaha Kuliner}

\begin{tabular}{cl}
\hline No & \multicolumn{1}{c}{ Tema } \\
\hline 1 & Peningkatan penjualan makanan/minuman yang dilakukan secara online \\
& selama masa PSBB \\
2 & Penerapan standar kesehatan di rumah makan/restoran \\
3 & Perubahan dalam pengolahan dan pengemasan makanan \\
\hline
\end{tabular}

\section{Penerapan Standar Kesehatan di Rumah Makan/Restoran}

Selama masa PSBB, pengusaha kuliner ini tidak membuka usaha mereka karena tidak boleh melayani makan di rumah makan/restoran. Namun setelah diberlakukan new normal atau kebiasaan baru di Kota Makassar, pengusaha kuliner mulai membuka rumah makan/restoran mereka. Namun dengan menerapkan standar atau kebiasaan baru dalam bertransaksi di rumah makan/restoran mereka.

Beberapa standar pelayanan yang diterapkan oleh informan di rumah makan/restoran mereka antara lain:

\section{Penyediaan fasilitas cuci tangan dan hand sanitizer}

Perubahan yang dilakukan antara lain menyediakan fasilitas cuci tangan seperti air mengalir dan sabun, sehingga pengunjung yang ingin makan di rumah makan/restoran mereka harus cuci tangan dulu baru masuk ke dalam. Mereka juga menyediakan hand sanitizer di tempat yang mudah terlihat dan terjangkau oleh pembeli.

"Waktu kami sudah mulai buka rumah makan lagi, yang kami siapkan pertama adalah tempat cuci tangan dan sabun dan hand sanitizer. Jadinya ini pasti menambah pengeluaran kami lagi" (Informan AV, IDI).

"Kami juga siapkan hand sanitizer di dekat kasir, jadi pembeli tidak khawatir lagi kalau sudah membayar pakai uang tunai. Dulunya tidak ada. Biasa saja” (Informan J, IDI).

\section{Pengaturan jarak kursi dan meja}

Salah satu kebijakan dalam upaya pencegahan Covid-19 adalah pengaturan jarak. Informan menyampaikan bahwa mereka berusaha mengikuti anjuran tersebut dan mengatur jarak meja dan kursi di rumah makan/restoran.

"Dulunya satu meja bisa 8 kursi sekarang kami atur menjadi hanya 4 kursi saja dengan jarak 1 meter lebih. Ada jarak antar pembeli jika mau makan di tempat." (Informan AB, IDI).

"Kami simpan sebagian kursi dan meja. Jadi ada jarak yang luas antar meja. Bahkan kami batasi kursinya hanya 2 saja. Dulunya bisa sampai 4 kursi" (Informan AV, IDI)

\section{Kewajiban menggunakan masker \\ Pengusaha kuliner ini menerapkan} aturan internal dalam pelayanan makanan di 
rumah makan/restoran mereka. Baik pemilik, pengolah makanan hingga konsumen wajib pakai masker. Meskipun masker yang digunakan umumnya berbahan kain atau masker non-bedah.

"Saya cukup ketat menerapkan aturan pakai masker bagi karyawan saya. Termasuk jika ada pembeli atau jasa delivery, mereka harus pakai masker yang benar baru boleh masuk ke toko kue kami" (Informan M, IDI).

\section{Penggunaan plastik pembatas}

Beberapa informan menambahkan pembatas pada rumah makan/restoran mereka. Pembatas plastik ini bertujuan untuk mengurangi kontak dengan pembeli sehingga pembeli tetap merasa aman dengan makanan yang disajikan.

"Ini baru kami tambahkan, kami kasi pembatas plastik supaya pembeli tidak langsung bersentuhan dengan makanan yang disajikan. Kalau dulu, pembeli bisa langsung mengambil makanan yang mereka suka." (Informan AV, IDI).

\section{Perubahan dalam Pengolahan dan Pengemasan Makanan}

Pandemi Covid-19 telah membuat pengusaha kuliner menjadi lebih berhati-hati dan memperhatikan cara pengolahan makanan dan minuman yang dijual. Pengusaha kuliner mulai menggunakan sarung tangan plastik sekali pakai dalam pengolahan makanan. Hal ini bertujuan untuk menjaga kepercayaan konsumen bahwa makanan yang disajikan telah diolah dengan aman dan sehat.

\section{"Sebelum pandemi, kami sudah berusaha mengolah makanan kami dengan cara aman dan bersih. Namun setelah pandemi ini, kami jauh lebih berhati- hati. Supaya konsumen tetap merasa aman." (Informan W, IDI).}

"Sejak pandemi ini, saya berusaha tidak menyentuh makanan yang kami olah sampai ke meja pembeli. Kami pakai sendok atau sarung tangan plastik jadi tidak menyentuh makanannya secara langsung" (Informan T, FGD).
Standar kebersihan dan keamanan makanan dan minuman yang diolah bukan hanya dilakukan pada proses pengolahan hingga penyajian makanan. Untuk pemesan makanan/minuman secara online, pengusaha kuliner mengemas makanan tersebut dengan rapi dan bahkan dengan tambahan plastik hingga $2-3$ lapis.

"Sekarang kami mengemas makanan yang dipesan online sampai doble-doble plastiknya. Supaya aman. Kalau dulu dibungkus satu kami sudah aman" (Informan S, FGD).

"Ya, kami bungkus lebih rapi dan tambahan plastik supaya konsumen kami merasa aman. Tapi saya pikir jasa delivery-nya pun sudah menerapkan standar kesehatan supaya makanannya tetap aman" (Informan I, FGD).

\section{PEMBAHASAN}

Social/physical distancing atau menjaga jarak sosial/fisik berarti menjaga jarak aman antara individu dan individu lain yang tidak serumah. Dalam skala besar, penerapan sosial distancing ini dilakukan dalam bentuk PSBB. (Centers for Disease Control and Prevention, 2020c) Penerapan PSBB dan protokol kesehatan merupakan hal yang penting dan tindakan yang paling efektif dalam upaya penanganan dan pencegahan penularan Covid19. (Qian \& Jiang, 2020)

Selama pemberlakuan PSBB di Kota Makassar diberlakukan, ada larangan beraktivitas di berbagai fasilitas publik termasuk perkantoran, pusat perbelanjaan dan rumah makan/restoran. Namun studi ini menemukan bahwa meskipun rumah makan/restoran ditutup selama PSBB, namun pengusaha kuliner menyatakan terjadi peningkatan penjualan makanan/minuman yang dilakukan oleh masyarakat secara online. Hal ini disebabkan karena aturan PSBB yang membatasi gerak masyarakat untuk mengakses makanan secara langsung serta tingginya kekhawatiran akan kekurangan pangan. (Nicola et al., 2020), (Niles et al., 2020) Sehingga masyarakat memilih melakukan pembelian makanan secara online ternyata

Pembelian makanan secara online selama masa PSBB atau lockdown juga meningkat di seluruh dunia seperti di negara- 
negara benua Eropa dan Amerika. Sehingga badan pengawasan obat dan makanan di negara-negara tersebut memantau secara ketat proses distribusi makanan yang dilakukan melalui pembelian online tersebut. (Rizou, Galanakis, Aldawoud, \& Galanakis, 2020)

Setelah diberlakukannya era kebiasaan baru, pengusaha kuliner dibolehkan membuka restoran/rumah makan. Perubahan penting dalam sistem pengolahan pangan yang dilakukan oleh pengusaha kuliner tersebut adalah dengan penerapan standar kesehatan di rumah makan/restoran yang dilakukan setiap hari. Hal ini mereka lakukan lebih ketat dibanding sebelum masa pandemi.

Pengusaha kuliner memperhatikan standar kesehatan dengan mengatur jarak meja dan kursi sehingga konsumen yang ingin makan di rumah makan/restoran mereka dapat tetap menjaga jarak. Mereka pun menyediakan tempat cuci tangan dengan sabun dan air mengalir, dan mewajibkan staf dan konsumen memakai masker. Perubahan dalam sistem pelayanan makanan yang diterapkan oleh pengusaha kuliner ini memenuhi standar keamanan pangan yang direkomendasikan oleh WHO untuk pengusaha kuliner. (WHO, 2020a)

Menurut WHO, upaya pencegahan Covid-19 dapat efektif dengan penggunaan masker, sering mencuci tangan dengan sabun dan air mengalir setidaknya selama 20 detik (Centers for Disease Control and Prevention, 2020b) atau dengan menggunakan hand sanitizer atau antiseptik berbahan dasar alkohol. (WHO, 2020b) Upaya ini sangat penting dalam membatasi penularan virus secara lokal. (Qiu, Chen, \& Shi, 2020)

Selain itu, WHO dan Centers for Disease Control and Prevention (CDC) pun menganjurkan agar pengusaha kuliner melakukan pembersihan dan disinfektan secara teratur terutama daerah-daerah yang sering disentuh. Tujuannya adalah untuk mencegah penularan Covid-19. (Lorraine, Carza, \& Maddumba, 2020) Sayangnya, dalam penelitian ini tidak ditemukan pengusaha kuliner melakukan disinfektan pada rumah makan/restoran mereka.

Selama masa pandemi dan era kebiasaan baru, keamanan pangan bukan hanya menjadi perhatian konsumen tapi juga pengusaha kuliner. Pengusaha kuliner menjadi lebih berhati-hati dalam pengolahan makanan/minuman yang akan dijual atau disajikan.

Dalam upaya menjaga kualitas dan keamanan makanan, mereka menggunakan masker dan sarung tangan plastik sekali pakai. Penggunaan sarung tangan dalam proses pengolahan makanan sangat dianjurkan oleh FDA (Badan Pengawas Obat dan Makanan Amerika Serikat) untuk menghindari kontak tangan secara langsung dengan makanan siap santap. (U.S. Food \& Drug Administration, 2020) Selama pada pandemi dan era kebiasaan baru, sangat penting untuk menjaga kepercayaan konsumen dengan menerapkan keamanan pangan dalam proses pengolahan dan penyajian makanan.

Dalam penelitian ini juga ditemukan bahwa pengusaha kuliner menerapkan standar keamanan pangan yang lebih ketat pada makanan yang dikemas atau dibeli secara online. Mereka menyiapkan makanan dalam wadah khusus lalu membungkus makanan/minuman dengan baik dan rapi serta membungkusnya lagi dengan kantong plastik hingga 2-3 lapis. Wadah dan kemasan sekali pakai harus digunakan untuk dalam mengemas makanan dengan baik untuk menghindari kontaminasi virus terhadap makanan. Pengemudi atau jasa pengantaran (delivery) pun harus menerapkan standar kesehatan yang benar dengan tetap menjaga jarak fisik saat mengambil dan mengantar makanan. (WHO, 2020a).

\section{KESIMPULAN DAN SARAN}

Perubahan dalam sistem pelayanan makanan yang diterapkan oleh pengusaha kuliner adalah dengan menerapkan standar kesehatan di rumah makan/restoran mereka seperti menyediakan fasilitas cuci tangan, pembatas plastik, menjaga jarak meja/kursi dan mewajibkan konsumen menggunakan masker. Dan yang paling penting adalah terjadi peningkatan keamanan pangan pada proses pengolahan makanan dengan mewajibkan pengolah makanan menggunakan masker dan sarung tangan plastik sekali pakai. Proses pengemasan makanan dibuat lebih rapi dan lebih ketat dengan menambahkan kantong plastik hingga dua lapis.

Pengusaha kuliner perlu melakukan pembersihan dan disinfektan secara rutin pada permukaan yang sering disentuh seperti meja dan kursi. Hal ini agar upaya pencegahan 
Covid-19 di sektor usaha kuliner dapat dilakukan lebih maksimal.

\section{DAFTAR PUSTAKA}

Centers for Disease Control and Prevention. (2020a). Food and Coronavirus Disease 2019 (COVID-19). Retrieved from https://www.cdc.gov/ coronavirus/2019ncov/ daily- life- coping/food-andCOVID-19. html.

Centers for Disease Control and Prevention. (2020b). Food Safety and Coronavirus Disease 2019 (COVID-19). Retrieved from https://www.cdc.gov/ foodsafety/ newsletter/food-safety-and-Coronavirus. html.

Centers for Disease Control and Prevention. (2020c). Social Distancing. Retrieved from https://www.cdc.gov /coronavirus/ 2019-ncov/prevent-getting-sick/socialdistancing.html.

Ceylan, Z., Meral, R., \& Cetinkaya, T. (2020). Relevance of SARS-CoV-2 in food safety and food hygiene: potential preventive measures, suggestions and nanotechnological approaches. Virus Disease, 31(2), 154-160. https://doi.org/ 10.1007/ s13337-020-00611-0.

European Commission. Directorate-General for Health and Food Safety. (2020). COVID19 and Food Safety: Questions and answers. European Commission. Directorate-General for Health and Food Safety.

Galanakis, C. M. (2020). The Food Systems in the Era of the Coronavirus (COVID-19) Pandemic Crisis. Foods, 9(523), 445472. https://doi.org/10.1146/annurev-soc060116-053252

Han, J., Zhang, X., He, S., \& Jia, P. (2020). Can the coronavirus disease be transmitted from food? A review of evidence, risks, policies and knowledge gaps. Environmental Chemistry Letters, (0123456789). https://doi.org/ 10.1007/ s10311-020-01101-x.

Kemenkes RI. (2020). Penetapan Pembatasan Sosial Berskala Besar di Wilayah Kota Makassar Provinsi Sulawesi Selatan dalam Rangka Percepatan Penanganan Corona Virus Disease 2019 (Covid-19).

Lorraine, B., Carza, R. D. D. M., \& Maddumba, D. A. (2020). A guide to the New Normal. Retrieved from https://app.adpc.net/sites/default/files/pub lic/ publications/ attachments/DOH 200825 - A Guide to The New Normal_compressed.pdf.

Naja, F., \& Hamadeh, R. (2020). Nutrition amid the COVID-19 pandemic: a multi-level framework for action. European Journal of Clinical Nutrition. https://doi.org/ 10.1038/s41430-020-0634-3.

Nicola, M., Alsafi, Z., Sohrabi, C., Kerwan, A., Al-Jabir, A., Iosifidis, C., ... Agha, R. (2020). The socio-economic implications of the coronavirus pandemic (COVID19): A review. International Journal of Surgery, 78 (January), 185-193. https://doi.org/10.1016/j.ijsu.2020.04.018

Niles, M. T., Bertmann, F., Belarmino, E. H., Wentworth, T., Biehl, E., \& Neff, R. (2020). The early food insecurity impacts of covid-19. Nutrients, 12(7), 1-23. https://doi.org/10.3390/nu12072096

Olaimat, A. N., Shahbaz, H. M., Fatima, N., Munir, S., \& Holley, R. A. (2020). Food Safety During and After the Era of COVID-19 Pandemic. Frontiers in Microbiology, 11(August). https://doi. org/ 10.3389/ fmicb.2020. 01854.

Qian, M., \& Jiang, J. (2020). COVID-19 and Social Distancing. Journal of Public Health (Germany), (Mikulska 2019). https://doi.org/ 10.1007/ s10389-02001321-z.

Qiu, Y., Chen, X., \& Shi, W. (2020). Impacts of social and economic factors on the transmission of coronavirus disease 2019 (COVID-19) in China. Journal of Population Economics, 33(4), 11271172. https://doi.org/10.1007/s00148020-00778-2

Rizou, M., Galanakis, I. M., Aldawoud, T. M. S., \& Galanakis, C. M. (2020). Safety of foods, food supply chain and environment within the Covid-19 pandemic. Trends in Food Science and Technology, 202(June).

U.S. Food \& Drug Administration. (2020). Best practices for retail food stores, restaurants, and food pick-up/delivery services during the COVID-19. U.S. Food \& Drug Administration. Retrieved from https://www.fda.gov/food/foodsafety- during- emergencies/ bestpractices-retail- food- stores-restaurantsand-food-pick- updelivery- services- 
during-covid-19\#employeehealth.

WHO. (2020a). Covid-19 and Food Safety: Guidance for food businesses: Interim guidance. WHO. https://doi.org/ 10.4060/ ca8660en.

WHO. (2020b). Media Statement: the role and need of masks during COVID-19 outbreak.
WHO. (2020c). WHO announces COVID-19 outbreak a pandemic. Retrieved from https://www.euro. who.int/en/ healthtopics/ health-emergencies/ coronaviruscovid-19/ news/ news/2020/3/whoannounces -covid-19- outbreak- apandemic. 